\section{Sustainability of Heritage Preservation in Academic Education of Architects in Lithuania}

\section{Jūratė Jurevičienè, Edita Riaubienè ${ }^{*}$, Dalius Vrubliauskas}

Vilnius Gediminas Technical University, Faculty of Architecture, Department of Architectural Fundamentals, Theory and Arts, Traku str. 1, Vilnius, LT- 01132 Lithuania

*Corresponding author: edita.riaubiene@vgtu.lt

$\Gamma$ crossef http://dx.doi.org/10.5755/j01.sace.21.4.19178

Research of urgent problems and new aspects of contemporary tendencies in architect education of the preservation of cultural heritage in Lithuania has been carried out by the team of Department of Architectural Fundamentals, Theory and Arts, Vilnius Gediminas Technical University. Within the framework of the "Sustainable rehabilitation of the historic towns in Europe" (SURE), project funded by EU with the collaboration among the Polish, Italian, Spanish and Lithuanian counterparts, Vilnius team has performed the research on the problems in emerging tendencies in the highest education on the preservation of the cultural heritage in Lithuania. The questionnaires for the opinion pooling were sent to the selected threefold type of the recipients: educational-scientific, public-state, and privateprofessional (Best practices handbook, 2017).

The research of enquire reflected devastating effect of recent processes of urban planning in Lithuania in the immovable cultural heritage area: neglect of cultural landscape value in urban planning of cities, concern of identity loss and negative impact of globalization, lack of proper maintenance and use of historic buildings. Contrary to these revealed problems plea of recent international strategic documents emphasizes variety of ways of contribution of historic areas in bettering of urban life.

Lack of ecological approach in urban heritage planning, tension between contents of academic programs and official aims of strategic documents ratified by the State, difference in expectations of theoreticians and practicing urban planners were revealed by the results of completed research.

The differences in attitudes of academicians and professionals, i.e. inadequate reflection of urban heritage in urban planning processes, shortcomings in integrating of local communities into preservation processes and academic education of architects were clearly stated. Variety of important issues in relation with protection of cultural heritage and sustainability was unveiled in academic education of architects in Lithuania. Provided questionnaires and collected results of the answers, after the completed analysis of the education programs and expert survey disclosed the shortage of ecological knowledge in the field of cultural heritage protection. Considering revealed problems and needs integration of sustainability and urban heritage preservation should be proposed as one of major target for the improvement of existing educational system of architects in Lithuania. Primarily targets to be hit by the alteration of the situation would be the reduction of the lack of ecological approach in urban heritage planning, diminished tension between contents of academic programs and official aims of strategic documents ratified by State and lowered difference in expectations among the theoreticians and practicing urban planners.

Keywords: architect education, expert survey, sustainability, urban heritage preservation.
JSACE $4 / 21$

Sustainability
of Heritage
Preservation in
Academic Education
of Architects in
Lithuania
Received
$2017 / 10 / 01$
Accepted after
revision
$2017 / 12 / 20$

Sustainability

of Heritage

Preservation in

of Architects in

Lithuania

Received

2017/10/01

revision

2017/12/20

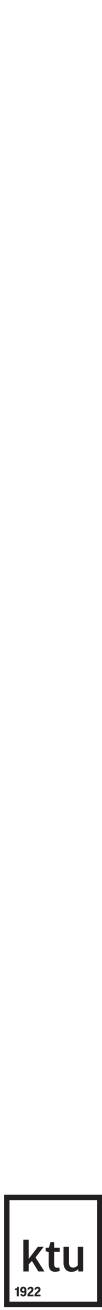

Journal of Sustainable

Architecture and Civil Engineering

Vol. 4 / No. 21 / 2017

pp. 17-22

DOI 10.5755/j01.sace.21.4.19178

(c) Kaunas University of Technology 


\section{Introduction}

\section{Methods}

Discussion and results
Contemporary urban development in Lithuania is often associated with disregard for urban cultural heritage. Many aspects of these negative phenomena could be related with existing system of architect education; however, no systematic research was accomplished from this point of view during the last decades. Research of the problems of heritage protection and architects' education has been carried out by the team of Department of Architectural Fundamentals, Theory and Arts of Vilnius Gediminas Technical University. Substantial number of urgent aspects of contemporary tendencies in architect education in relation with preservation of cultural heritage were revealed. The research team focused on experience and determinants distinctive for Lithuania in contemporary period.

The major aim of the research was to generalize the results of expert valuation, and by naming the key problems of architects' education, and to propose the structure and the contents of new master program framework. The investigation covered two aspects: critical analysis of existing problems of urban cultural heritage preservation in Lithuania and diagnose of the teaching system status. The conclusions of overall research were achieved in comparative assessment of the results of both analyses. After final evaluation of basic problems in practice of urban heritage protection and academic education the proposals for new master program were drafted.

The questionnaires for the opinion pooling were sent to 50 recipients. The replies were received from the 25 and completed questionnaires were received from 18 respondents. The answers of the respondents revealed basic similarities in evaluation of practical problems of heritage protection and system of education. Critical evaluation of current status and expectations in education of architects were highlighted. Difference appeared mostly in presented expectations of the theoreticians and of the practicing urban planners. Obtained data were used in feasibility study to propose the optimal program of academic Architecture Master studies.

The study is based largely on the data of the expert survey. Of particular importance was the establishment of the expedient questionnaire. The structure of questionnaire corresponds to two principal parts. One is dealing with actual situation, asking respondents about the issues and problems related to heritage protection and revitalization of historical towns that are taught on architectural studies, what qualifications architects have in the field, to characterize the general approach to heritage protection, tell the positive and negative remarks on current education of architects in the field. The second part of questions mostly explained the provisions and expectations of the future architecture study program in heritage protection and revitalization of historical towns. The respondents were asked to list and describe the courses, characterize the form and the scope of contact with practice in the curricula, to present the alumnus profile in sustainable urban regeneration, to describe the curriculum content and structure, to present a proposal for a model curriculum in the field of heritage protection and revitalization of historical towns.

In order to clarify the situation as closely as possible this two-part questionnaire was addressed to three groups of respondents: educational-scientific (academic), public-state (administrative), and private-professional (architectural practitioners). The obtained data was analyzed, grouped, summarized and abstracted. The results of the survey were compared among the respondents in each group and among all the three groups. Finally, holistic evaluation of the experts' survey with legal contemporary requirements for urban preservation was performed. The generalized results of the survey were synthesized to achieve the findings of the study.

The comparison of international and national legal documents revealed similarity of concept and declared principles of sustainable development. Contemporary international strategic documents on sustainable development and preservation of cultural heritage emphasize variety of ways of contribution in bettering of urban life in historic areas (Policy document..., 2015). However, mech- 
anism of their implementation, responsibility of participants, role of local inhabitants and communities in urban development and heritage protection are still indeterminate in Lithuanian legal system. Inadequacy and contradictions of legal national requirements are more than evident.

Architecture education context in Lithuania is rather homogeneous. Currently in Lithuania three schools educate architects (Vilnius Gediminas Technical University, Kaunas University of Technology and the Vilnius Academy of Arts), but the content of all Architecture study programs mainly based on the Directive 2013/55/EU of the European Parliament and of the Council (Directive..., 2013), and the curriculum complies with Article 46 of Directive and the 11 points for architect's qualification. It is important to mention, that the essence of the 11 points for architect qualification haven't been revised since 1985, and the concept of sustainability was poorly actualized there. The revised Charter of Architectural Education (Charter..., 2011) expanded the competence of the architect with ,the awareness of responsibilities toward human, social, cultural, urban, architectural, and environmental values, as well as architectural heritage and adequate knowledge of the means of achieving ecologically responsible design and environmental conservation and rehabilitation". The demand for professionals in urban reconstruction, regeneration, revitalization was obvious in Lithuania since 1960, but despite the obvious need, the specialists with great competence in this field were not educated. After the survey of the content of architecture study programs in Lithuania that mostly have the goal to educate the universal creative architect who is able to create architectural designs, the provided knowledge, competencies and skills very poorly meet the special requirement of the professional of heritage preservation and urban revitalization.

Provided inquiry and collected results of the answers to the questionnaires on the education programs by the country universities and selected practicing professionals reflected need of cohesive approach to the overall heritage values of historic urban environment. If property is owned by the State or municipality requirements for conducting architectural design are restricted by the variety of national laws: Law for Public Purchase, Law on Protection of Immovable Cultural Properties, Law on Construction, Law on Spatial Planning, and their amendments are proposed and approved very often. These basic documents should be implemented by huge number of different bylaws; however, no legal requirements establishing obligation of holistic (complex) investigations and survey of cultural heritage are still not determined as obligatory (Republic..., 2017). Contemporary legal regulation of heritage protection in Lithuania is not enough effective as it was revealed by accomplished inquiry. This situation could be explained as rooted in two huge shortages of existing laws: disregard of holistic scientific research in heritage protection and formal approach to participation of local communities. The opinion of the respondents could be accepted as symptomatic because the majority of them are the researchers of cultural heritage and experienced practicians having good knowledge of contemporary problems in the field of heritage protection.

Existing licensing system in the field of cultural heritage protection in Lithuania is based upon variety of requirement for applicant, but almost every architect with 3 years of practical experience of architectural design work is able to obtain this license if his practical work was related with a heritage site or structure. Procedure of licensing is determined as complicated, however observance of preservation of architectural value and estimation to authenticity to heritage do not play enough important roles for possibility to obtain the license (LR Kultūros..., 2016).

Possibilities to work in the field of urban heritage administration and management are limited. Despite of these difficulties the main competencies of graduates, according the opinion of experts, should be in constant perfection and improvement of qualification. Providing excellence of heritage preservation and urban regeneration, the theoretical knowledge and practice must be combined. The master study program Rehabilitation of the Historic Towns should be interdisciplinary and comprise various and diverse aspects of urban heritage preservation.

The distributed and lately re-monitored questionnaire draw down the tendency, in the major amount 
of responses, on the nature and specifics of the education of Master Architects. In the field of qualifications and skills required for the successful work with heritage protection and urban rehabilitation it had shown the necessity to provide comprehensive excellence for education in heritage preservation and urban regeneration, with obligatory to combine theoretical knowledge and practice.

Architectural Master studies on the mentioned above range of education subjects might be treated less than the weak ones without multidisciplinary way of setting up the range of the teaching modules on 1) exploring the understanding and identification of cultural values, 2) deepen essential knowledge on the legislation system in the preservation of cultural heritage, 3) involvement of the societal dimension as end user while trying to ensure the sustainable quality of the preservation projects. The same need was expressed to recover the forgotten in the country knowledge and crafts of the historic tradition in the art of construction, application of the modern technologies in preservation of material authenticity of historic structures and major methods of contemporary technical preservation of heritage.

The urban dimension in foreseen curricula, as it was stated by the number of the responders, is obviously lacking the abilities of the specialists to understand urban and social context of urban structures or smaller in scale, but densely build up sites and importance of the dialog between the participating parties, as the major trend in preservation of the cultural heritage of the 21 st century. What concerns the teaching specifics about the problematic related to the protection of heritage and revitalization in the light of the desirable qualifications to be achieved by the Master students, the following scope of aspects had been accentuated by the responders: 1) to deepen the abilities allowing to understand urban and social context of structure or site under the analysis, 2) development of ability to assess main features of cultural values, to reveal main threats to cultural value and scientific methods to evaluate them, 3) to explore wider the range of abilities of the assessment of the area from the architectural, spatial, functional, technical and social points of view, 4) to apply the planning and design regulations to historic cities, principles of sustainable development in the process of urban revitalization, to analyze the heritage research data and to understand the historic formation/development peculiarities of historical urban structures.

From the point of the general approach to heritage protection and revitalization of historical cities, which should be taught at the faculties of architecture with in the Master studies, responders pointed out the idea of the increased respect towards the cultural heritage, while planning, using it at present and maintain it safeguarded for the future generations. The ways of executing that would be various, according to the responders, but always based on open and thorough discussion between the decision makers, stakeholders and politicians, professionals-practitioners and scientists, and receivers of the results - local communities of society (Council of...; FARO, 2005).

It was noted by the responders, that in order to achieve that contemporary and liberal approach to heritage preservation: 1) while aiming to harmonize them, to follow the problematic way of studying, by presenting the various viewpoints, enabling pluralistic attitude, positive and critical, 2) to strive for the concord of the desire and will to preserve heritage values and adapt heritage to contemporary needs and requirements, 3) to pursue for the harmonization of contradictions of preservation and development, by the sustainable attitude. The insights of the experts can be summarized by this quotation: "the revival of the historic city must be oriented to the social and human dimensions, by applying principles of sustainability" (Munoz-Vinas, 2005).

Other positive and negative remarks on current education of architects and their attitude to heritage protection and revitalization of historic cities has been stressed as follows:

Pointing out the current status of the education of architects in the field of the heritage protection, with the present aim, to prepare the wide profile architect, to educate multi-faceted, versatile skilled architect, it was doubtlessly stressed that, specialists' competencies in heritage preservation and urban revitalization are not sufficiently emphasized. 
Architects usually lacking knowledge of history and development of heritage preservation and also the contemporary preservation methods, principles and trends of city regeneration, as well as shortage of knowledge of a holistic approach to the historic environment;

- As one among other reasons for the improper preparation of the architect for urban regeneration activities is the current negative attitude of the architectural community to heritage protection as a fully-fledged architectural activity was underlined and the obvious need to reduce the opposition of new architecture and heritage while bringing together architects, that create the new architecture and who preserve and revitalize the historic architecture was stressed.

- The overall need to pay much more attention to foster the architect's empathy for community needs and interests, to shape the deep, flexible and adaptive understanding of the diversity of cultural heritage value was notable in the plea of answers by the responders.

The analysis of the architecture education programs in Lithuania and expert survey revealed shortage of understanding of sustainable urban development. The need of effective means of integration of urban development and urban heritage preservation should be proposed by contemporary architects' educational system.

The main objective of the expected Architecture Master study program will be to cultivate and foster the holistic approach of the professional. It means that architect should perceive and understand the urban heritage as the multifaceted phenomenon, having great potential to serve the future society.

This indicates that the program should aim for multidisciplinary, linking different aspects, such as historical, spatial, functional, technological, social etc. In this case, the program should maintain the problematic nature, providing the optimal coordination and integration of theoretical teaching and practical training. The tighter relations with challenges of practical experience of urban heritage preservation could help to achieve the educational goals of contemporary architect.

Many problems highlighted by the respondents could be explained by the basic shortages and contradictions of contemporary legal system: disregard of holistic scientific research in heritage protection and formal approach to participation of local communities. That's why, beside the development of the architect's abilities to perceive and assess the cultural value, to understand the urban and social context, to explore the place according different views and aspects, to apply legal regulations, principles of sustainable development and modern heritage preservation technologies, the focus in the study program will be made on the incorporation of the social (communal / societal) aspect in to the educational process. This particular element, the dialog of all the participating parties, as the integral part of the modern life, in the program will provide the possibility to be sure that the solution proposed and anticipated results are matching the range of the needs and expectations of those who will maintain the outcomes of the rehabilitation afterwards.

The research carried out revealed the need to have more comprehensive and thorough academic education in the field of sustainable preservation of urban and architectural heritage. It should be not limited to Architecture Master level studies. The provisions of sustainable urban and architectural design must be introduced already on the Bachelor level.

The research was carried out within the framework of the project funded by EU (Erasmus+) "Sustainable Rehabilitation of the Historic Towns in Europe" (SURE). We greatly appreciate the Lithuanian experts, who participated in the survey and provided the competent response to the questionnaire: D. Dijokiene, D. Klajumienè, J. Glemža, V. Petrušonis, P. Grecevičius, G. Tiškus, V. Janušauskaite, V. Kundrotas, E. Karalevičienè, R. Kepežinskienè, R. Kraujalis. Special thanks for the project manager $\mathrm{D}$. Traškinaite.

\section{Conclusions}

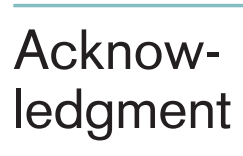




\section{References}

Best practices handbook "Contemporary realities and needs of sustainable urban rehabilitation". Edited by Szmygin, B. Lublin University of Technology; 2017.

Charter UNESCO/UIA for Architectural Education, 2011. Available on: www.uia-architectes.org/sites/ default/files/charte-en.pdf

Council of Europe framework convention on the value of cultural heritage for society, FARO, 2005. Available on: https://rm.coe.int/1680083746

Directive 2013/55/EU of the European Parliament and of the Council of 20 November 2013 amending Directive 2005/36/EC on the recognition of professional qualifications and Regulation (EU) No 1024/2012 on administrative cooperation through the Internal Market Information System ('the IMI Regulation') Text with EEA relevance. https://publications.europa.eu/en/publication-detail/-/publication/7508086d-76dc-11e3-b889-01 aa75ed71a1/language-en

Jurevičienè J., Riaubienè E., Vrubliauskas D. The teaching of the heritage protection and revitalisation of historic cities at the faculties of architecture in Lithuania. in Best Practices Handbook "Contemporary realities and needs of sustainable urban rehabilitation". Ed. Szmygin, B. Lublin University of Technology, 2017, 115-136.

LR Kultūros ministro isakymas “Dèl specialistų vyk- dančių nekilnojamojo kultūros paveldo taikomuosius mokslinius ardomuosius tyrimus, rengiančių tvarkomuju paveldosaugos darbu projektus, atliekančių tvarkomuosius paveldosaugos darbus bei vadovaujančių tokiems darbams, atliekančių paveldosaugos ekspertizę, atestavimo taisyklių ir nekilnojamojo kultūros paveldo apsaugos specialisto atestato formos patvirtinimo", 2016 m. gruodžio 30 d. Nr. IV-1012 [Description of licensing order of professionals, preparing documents of special planning for protection of cultural heritage. Minister of Culture and Minister of Environment", 30 December 2016 No [V-1012]. Available at: http://www.kpd. lt/uploads/Veiklos\%20sritys/NKPA\%20specialistu\%20atestavimo\%20tvarkos\%20apraso\%20tvirtinimo\%20isakymas.pdf.

Munoz-Vinas, S. Contemporary theory of conservation, Elsevier, 2005.

Policy document for the integration of a sustainable development perspective into the processes of the World Heritage Convention. General assembly of states parties to the World Heritage Convention at its $20^{\text {th }}$ session (UNESCO, 2015).

Republic of Lithuania Law on protection of immovable cultural heritage. 22 December 1994 No I-733. Valid version till 30 September, 2017. Available at: http:// www.heritage.lt/t_aktai/istatymai/nkpai_engl.htm .

\section{About the authors \\ About the}

JŪRATÉ JUREVIČIENÉ

Professor, Dr

Vilnius Gediminas Technical University, Faculty of Architecture, Department of Architectural Fundamentals, Theory and Arts

\section{Main Research Area}

Preservation of cultural landscape and architecture

\section{Address}

Traku str. 1, Vilnius, LT- 01132

Lithuania

Tel. +37068969345

E-mail: jurate.jureviciene@vgtu.lt

\section{EDITA RIAUBIENE்}

Assoc. Professor, Dr

Vilnius Gediminas Technical

University, Faculty of Architecture, Department of Architectural

Fundamentals, Theory and Arts

\section{Main Research Area}

Architectural education, Architectural Heritage

\section{Address}

Traku str. 1, Vilnius, LT- 01132 Lithuania

Tel. +37061216573

E-mail: edita.riaubiene@vgtu.lt

\section{DALIUS VRUBLIAUSKAS}

Assoc. Professor

Vilnius Gediminas Technical University, Faculty of Architecture, Department of Architectural Fundamentals, Theory and Arts

\section{Main Research Area}

Architectural Heritage Preservation

\section{Address}

Traku str. 1, Vilnius, LT- 01132

Lithuania

Tel. +37061812169

E-mail: dalius.vrubliaukas@vgtu.lt 